\title{
STRATEGI PENGEMBANGAN DESA SEKITAR CANDI BOROBUDUR BERDASARKAN TIPOLOGI POTENSI KEPARIWISATAAN
}

\author{
Akbar Preambudi \\ Dosen Prodi Arsitektur, Fakultas Sains dan Teknologi, Universitas Teknologi Yogyakarta
}

\begin{abstract}
The villages around Borobudur Temple have many tourism potentials that feel drowned by all the attention devoted to Borobudur Temple. Management of Borobudur temple with excessive business systems resulted in prosperity or poverty problems experienced by the people in the villages around Borobudur.

In relation with the determination of the development potential model for tourism, then this study adopts the dynamics of tourism development proposed by Miossec (Pearce 1989). Evolutionary model is based on four factors that may affect the development, namely; (1) resort; (2) transport; (3) tourist behavior; (4) attitudes of decision makers and population of receiving region. Factors that affect the "resort aspects" are the existence of recreation facilities and geographical location in the plains. Factors that affect the "transport aspects" are the existence of many modes of transportation and impassable by public transport routes. Factors that affect the "tourist behavior aspect" are the charter travelers type and leisure travelers type. Factors that affect the aspect of "attitudes of decision makers and population of receiving region" are the antagonism behavior of the public and the local officials that are less supportive of tourism.
\end{abstract}

Keywords: Village; Tourism; Potential; Typology; Strategy.

\section{Pendahuluan}

\section{Latar Belakang}

Kegiatan pariwisata selalu melibatkan masyarakat dan membawa berbagai dampak terhadap masyarakat setempat. Sektor industri pariwisata merupakan salah satu sektor yang terus menerus dilakukan oleh pemerintah secara nasional maupun global.

Desa-desa sekitar Candi Borobudur memiliki banyak potensi kepariwisataan yang dirasa tenggelam akibat semua perhatian ditujukan ke Candi Borobudur. Pengelolaan Candi Borobudur dengan sistem bisnis yang berlebihan mengakibatkan persoalan kesejahteraan atau kemiskinan yang dialami oleh masyarakat di desa-desa sekitar Candi Borobudur.

Meningkatnya kunjungan wisatawan ke masing masing desa, sekaligus mengembangkan dan meningkatkan kesejahteraan masyarakat di kawasan Candi Borobudur karena desa wisata melibatkan secara aktif dan menyeluruh peran serta masyarakat.Ada beberapa desa yang mengalami perubahan terutama semenjak wisatawan mulai masuk ke desa mereka. Namun demikian tidak semua desa mampu merespon kegiatan pariwisata secara cepat dan baik.

\section{Tujuan Penelitian}

Tujuan dari penelitian ini adalah memetakan tipologi desa-desa sekitar Candi Borobudur berdasarkan potensi kepariwisataannya, mengidentifikasi faktor-faktor yang berperan dalam pengembangan potensi kepariwisataan berdasarkan tipologi yang diketahui, dan menentukan strategi pengembangan berdasarkan tipologi yang diketahui.

\section{Manfaat Penelitian}

Diharapkan penelitian ini dapatmeningkatkan pengetahuan tentang arsitektur pariwisata, mengembangkan kawasan desa wisata dan mengembangkan ruang suatu kawasan khususnya kawasan desa wisata.

\section{Tinjauan Pustaka}

Teori Miossec

Sehubungan dengan penentuan model pengembangan potensi obyek wisata, maka dalam studi ini mengadopsi dinamika pengembangan pariwisata yang dikemukakan oleh Miossec (Pearce 1989). Model evolusi didasarkan pada empat faktor yang dapat mempengaruhi pengembangan, yaitu; (1) resort; (2) transport; (3) tourist behavior; (4) attitudes of decision makers and population of receiving region.

Gambar 1. Dinamika Pengembangan Pariwisata menurut Miossec

Sumber : Tourist Development, Douglas Pearce

Model Miossec menyajikan beberapa aspek yang berguna. Pembangunan wilayah dalam ruang dan

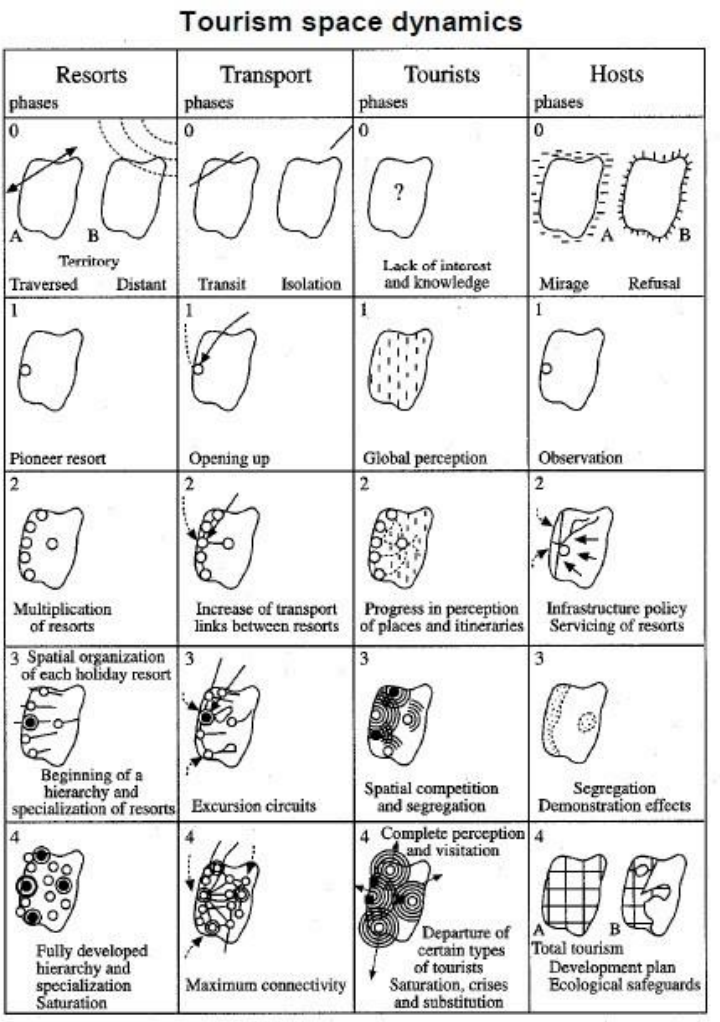


waktu. Gagasan ruang / waktu evolusi sangat penting baik dalam analisis proses masa lalu serta dalam perencanaan pembangunan masa depan. Perkembangan ini dilihat secara keseluruhan, perubahan perilaku wisatawan dan orang lokal berhubungan erat dengan peningkatan jumlah resort dan perluasan transportasi jaringan.

\section{Tipologi}

Schulz (1980) mengungkapkan, bahwa tipologi merupakan konsep yang dipakai untuk mendekripsikan kelompok obyek tertentu berdasarkan atas kesamaan sifat yang mendasar atau fundamental dan yang berupaya memilah - milah atau mengklasifikasikan suatu bentuk keberagaman dan keseragaman jenis tertentu. Tipologi dapat didefinisikan sebagai sebuah konsep yang memilah sebuah kelompok obyek berdasarkan kesamaan sifatsifat dasar, atau dapat diartikan pula bahwa tipologi adalah tindakan berfikir dalam rangka pengelompokan (Moneo dalam Mastuti, 2013).

\section{Metode Penelitian}

\section{Lingkup Studi dan Wilayah Penelitian}

Lingkup wilayah penelitian ini adalah seluruh desa di Kecamatan Borobudur, antara lain: 1.Bigaran; 2.Borobudur; 3.Bumiharjo; 4.Candirejo; 5.Giripurno; 6.Giritengah; 7.Karanganyar; 8.Karangrejo; 9.Kebonsari; 10.Kembanglimus; 11.Kenalan; 12.Majaksingi; 13.Ngadiharjo; 14.Ngargogondo; 15.Sambeng; 16.Tanjungsari; 17.Tegalarum; 18.Tuksongo; 19.Wanurejo; dan 20. Wringinputih.

\section{Metode Penelitian dan Analisis Data}

Penelitian ini dilakukan dengan observasi lapangan, dengan melihat fenomena-fenomena yang terjadi pada lokasi penelitian dan mengamati subjek penelitian. Hasil observasi yang sudah didapat, diubah menjadi data digital.

Untuk memetakan tipologi desa-desa sekitar Candi Borobudur berdasarkan potensi kepariwisataan dengan cara menganalisis temuan-temuan di lapangan kemudian dikompilasikan dengan teori maupun data lainnya. Pengidentifikasian faktor-faktor yang berperan dalam pengembangan potensi kepariwisataan dilakukan dengan cara menentukan faktor-faktor berdasarkan pada faktor pengaruh dari teori dan faktor pengaruh lokal. Penentuan strategi pengembangan menggunakan metode IPA (Importance Performance Analysis) yang menghasilkan tipe kuadran strategi pengembangan.

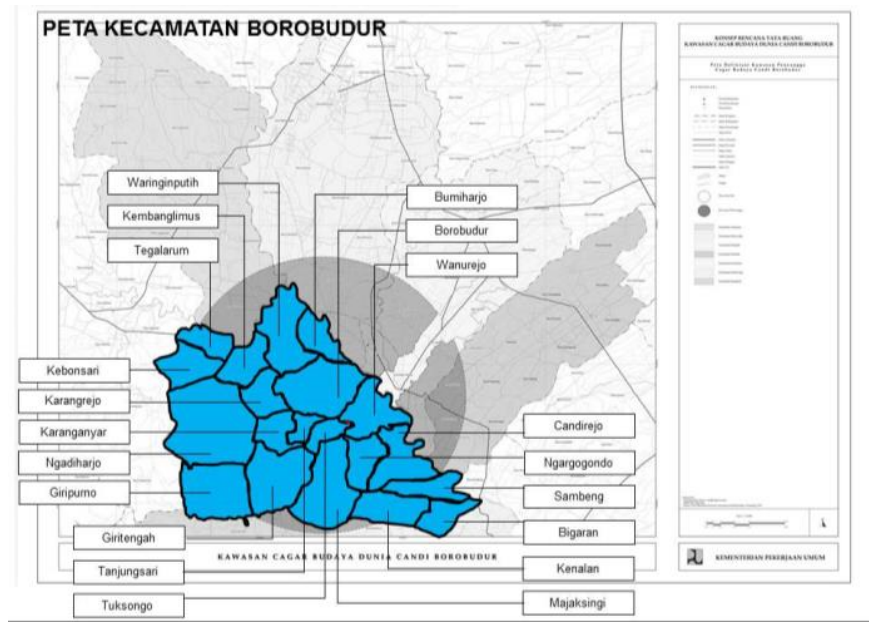

Gambar 2. Peta Kecamatan Borobudur

Sumber : PT. TAMAN dan

www.borobudurheritagevillage.com

\section{Hasil dan Pembahasan}

\section{Tipologi Desa-Desa di Sekitar Candi Borobudur}

Tipologi desa-desa sekitar Candi Borobudur dipetakan berdasarkan potensi kepariwisataan dengan cara menganalisis temuan-temuan di lapangan kemudian dikompilasikan dengan teori maupun data lainnya. Tipologi potensi menghasilkan tipe desa berdasarkan fase dalam teori Miossec seperti pada Tabel 1.

Tabel Penjabaran Penilaian Tipologi Desa-Desa di Sekitar Candi Borobudur

\section{Tabel 1 Penjabaran Penilaian Tipologi Desa-Desa di Sekitar Candi Borobudur}

\begin{tabular}{ccc}
\hline No. & Hasil tipologi & Nama Desa \\
\hline A & Tipe 1 & - \\
B & Tipe 2 & Bigaran, Giripurno, \\
& & Kenalan, dan Sambeng.
\end{tabular}

C Tipe 3

$\mathrm{D}$

Tipe 4

E Tipe 5
Karanganyar, Karangrejo,

Kembanglimus, dan Wringinputih

Bumiharjo, Giritengah, Kebonsari, Ngadiharjo, Ngargogondo, Tanjungsari, Tegalarum, dan Tuksongo.

Borobudur, Candirejo, Majaksingi, dan Wanurejo.
Mulai ada pembangunan resort sebagai perintis; Mulai dibukanya jaringan transportasi; Wisatawan mulai memiliki informasi / persepsi secara global mengenai daerah tujuan wisata; dan Kebijakan pemerintah dan tanggapan masyarakat masih terbatas pada tahap pengamatan (observasi)

Keberhasilan resort wisata perintis mempengaruhi perkembangan dan pembangunan fisik di dalam kawasan serta bagaian lain dari kawasan dalam tahap selanjutnya (keseragaman resort); Bertambahnya jaringan transportasi yang menghubungkan antar resort; Semakin meningkatnya persepsi wisatawan terhadap daerah tujuan wisata dan perjalanan wisata; Adanya kebijakan pemerintah di bidang infrastruktur yang melayani kawasan tersebut.

Resort mulai terorganisir dan memiliki hirarki; Mulai tersusunnya rute perjalanan wisata;Mulai adanya persaingan tempat dan terjadi pemisahanpemisahan; dan Bertambahnya fasilitas dan jaringan transportasi, perubahan sikap dalam menerima wisatawan dan kegiatan pariwisata oleh penduduk lokal.

Resort telah memiliki spesialisasi dan hirarki yang jelas; Jaringan transportasi dari tingkat keterhubungan dalam wilayah mencapai titik maksimal; Mulai diterapkannya kontrol perencanaan, dan mulai terbentuk dan berkembang jenis - jenis wisata tertentu; dan Spesialisasi kawasan sesuai kapasitas dan daya tarik bagi kawasan. 


\begin{tabular}{|c|c|c|c|}
\hline \multicolumn{4}{|c|}{ Tabel 2 Strategi pengembangan } \\
\hline No. & Tipe Kuadran & Nama Desa & Strategi Pengembangan \\
\hline A & Kuadran I & - & \\
\hline B & Kuadran II & $\begin{array}{l}\text { Karanganyar, } \\
\text { Kembanglimus, Karangrejo } \\
\text { Majaksingi, Wringinputih } \\
\text { Candirejo, Borobudur, dan } \\
\text { Wanurejo. }\end{array}$ & $\begin{array}{l}\text { Desa - desa yang termasuk dalam kuadran II dianggap desa yang berpartisi } \\
\text { baik dalam pariwisata terhadap keberadaan objek wisata Candi Borobudur. } \\
\text { Desa - desa ini diharapkan meningkatkan kualitas potensi wisata yang ada } \\
\text { pada tiap desa dan dapat terus mempertahankan prestasi atau keunggulan } \\
\text { desa yang sudah dimiliki. }\end{array}$ \\
\hline $\mathrm{C}$ & Kuadran III & $\begin{array}{l}\text { Giritengah, Tanjungsari, } \\
\text { Kebonsari, Ngargogondo, } \\
\text { Ngadiharjo, Tuksongo, } \\
\text { Sambeng, Bigaran, } \\
\text { Kenalan, Giripurno. }\end{array}$ & $\begin{array}{l}\text { Desa - desa yang termasuk dalam kuadran III dianggap desa yang tidak } \\
\text { berpartisi baik dalam pariwisata terhadap keberadaan objek wisata Candi } \\
\text { Borobudur. Desa - desa ini tidak terlalu diharapkan dalam pengembangan } \\
\text { pariwisata sehingga pihak pemerintah atau pihak lain yang terkait tidak } \\
\text { perlu memprioritaskan atau memberikan perhatian terhadap desa - desa } \\
\text { tersebut. }\end{array}$ \\
\hline $\mathrm{E}$ & Kuadran IV & Bumiharjo dan Tegalarum & $\begin{array}{l}\text { Desa - desa yang termasuk dalam kuadran IV dianggap desa yang kurang } \\
\text { berpartisi baik dalam pariwisata terhadap keberadaan objek wisata Candi } \\
\text { Borobudur. Desa - desa ini masih bisa diharapkan dalam pengembangan } \\
\text { pariwisata. Pihak pemerintah atau pihak lain yang terkait diharapkan tidak } \\
\text { memprioritaskan alokasi sumber daya terhadap pengembangan desa - desa } \\
\text { ini tetapi diharapkan mengalokasikan sumber daya tersebut kepada faktor } \\
\text { - faktor lain yang mempunyai prioritas penanganan lebih tinggi yang masih } \\
\text { membutuhkan peningkatan. }\end{array}$ \\
\hline
\end{tabular}

Gambar Peta Tipologi Desa-Desa di Sekitar Candi Sumber : Analisa Penulis

\section{Faktor-Faktor Berpengaruh}

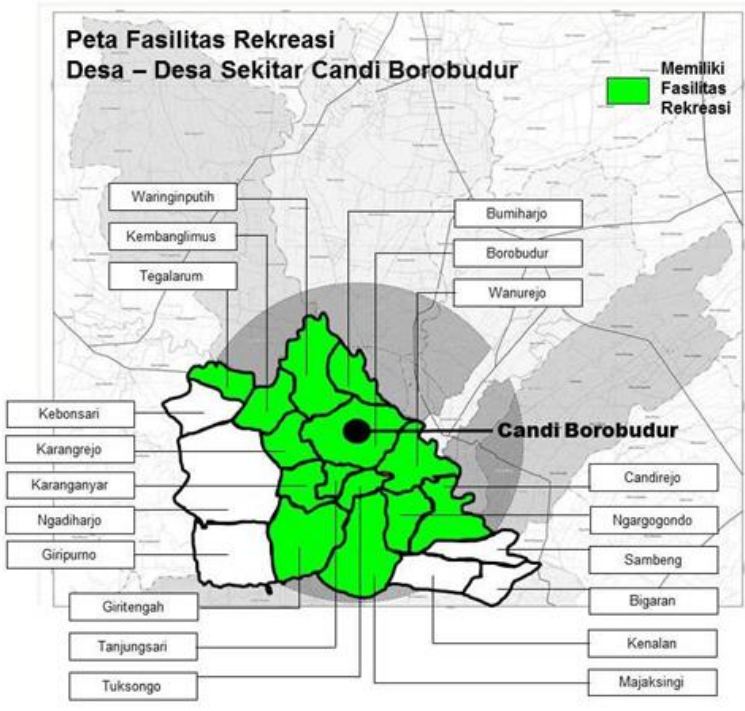

Sumber : Analisa Penulis

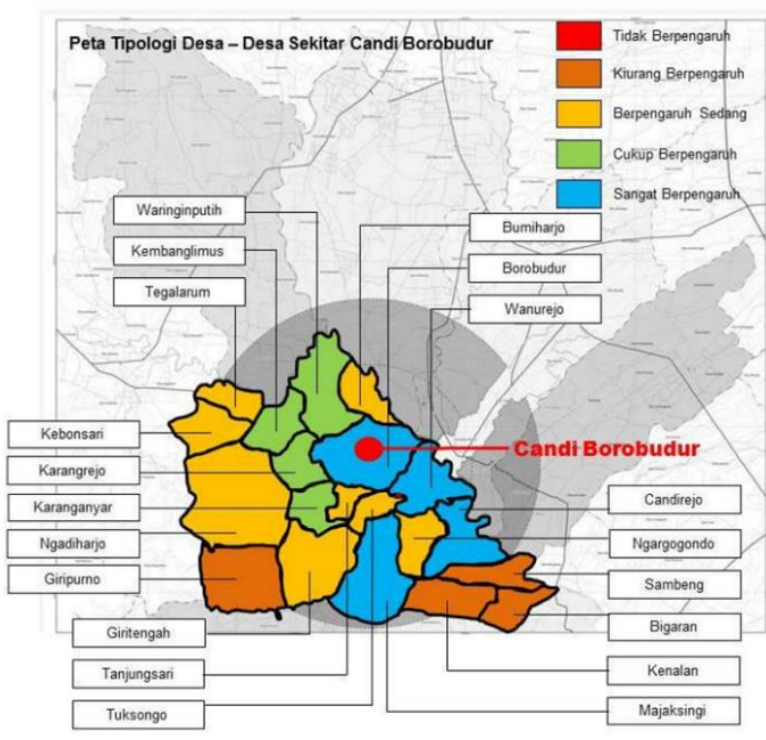

Sumber : Kecamatan Borobudur Dalam Angka, Tahun 2014
Pengidentifikasian faktor-faktor yang berperan dalam pengembangan potensi kepariwisataan dilakukan dengan cara menentukan faktor-faktor berdasarkan pada faktor pengaruh dari teori dan faktor pengaruh lokal. Faktor-faktor yang berpengaruh terhadap aspek resort yaitu adanya fasilitas rekreasi dan letak geografis di dataran.

Faktor yang berpengaruh terhadap aspek transport yaitu adanyamulti moda dan dilewati rute angkutan umum.

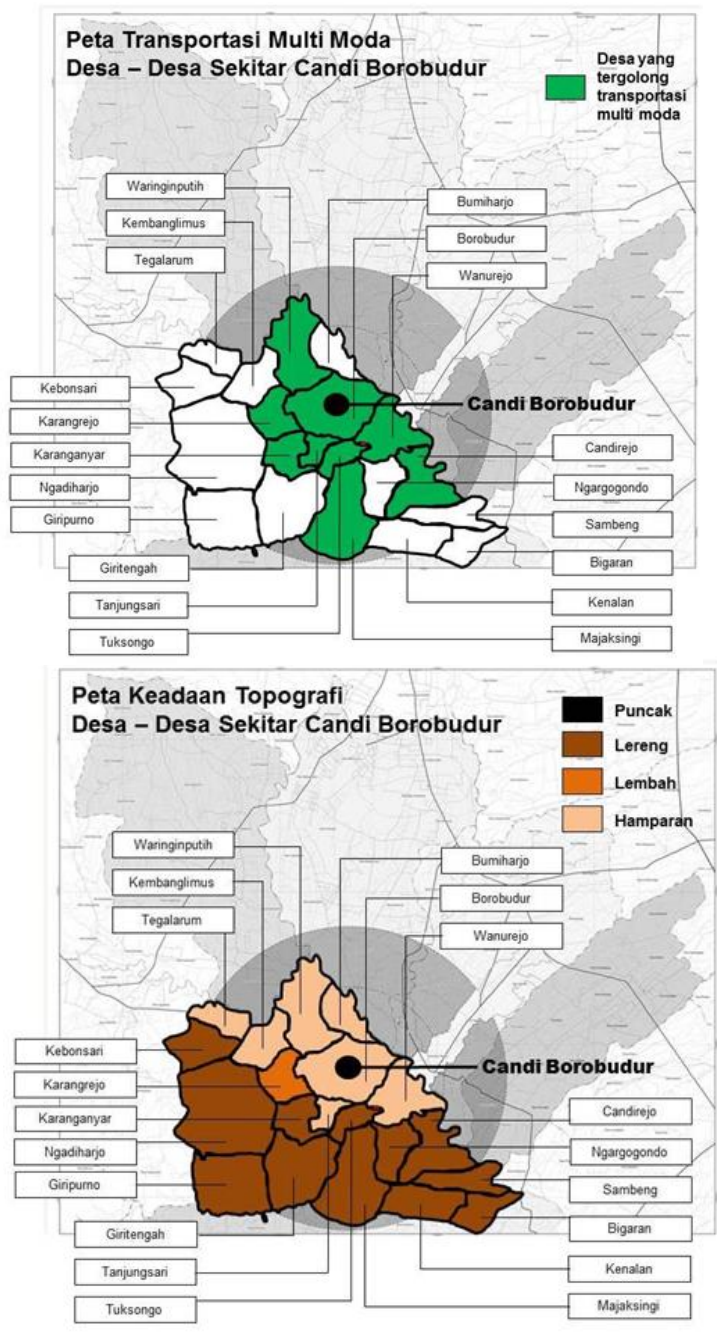

Sumber : Analisa Penulis 


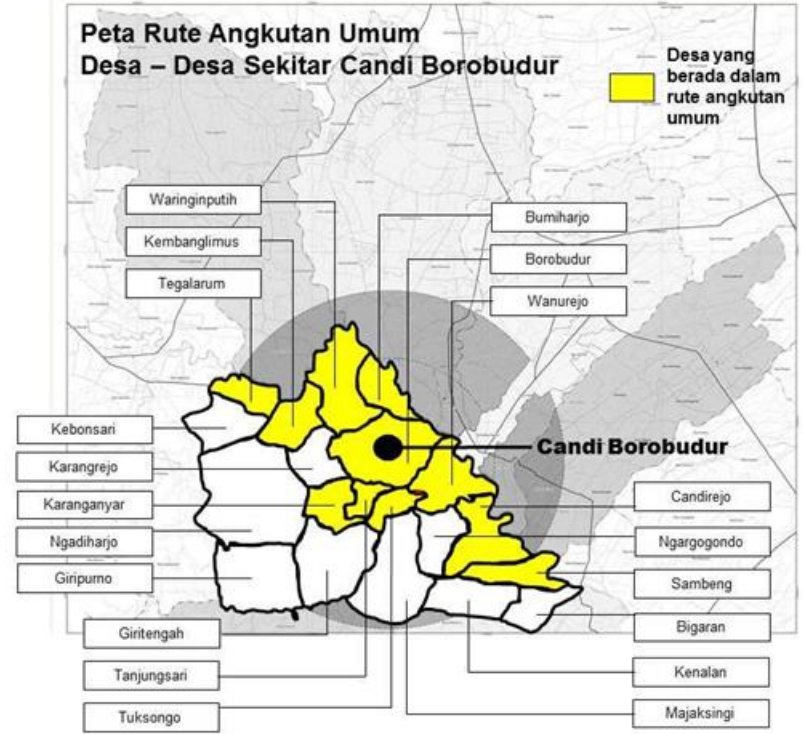

Sumber : Hasil Observasi Penulis

Faktor yang berpengaruh terhadap aspek tourist behaviour yaitu tipe wisatawan charter dan tipe wisatawan rekreasi.

Gambar Peta Tipe Wisatawan Charter Yang

Mengunjungi Desa - Desa di Sekitar Candi Borobudur

Sumber : Analisa Penulis

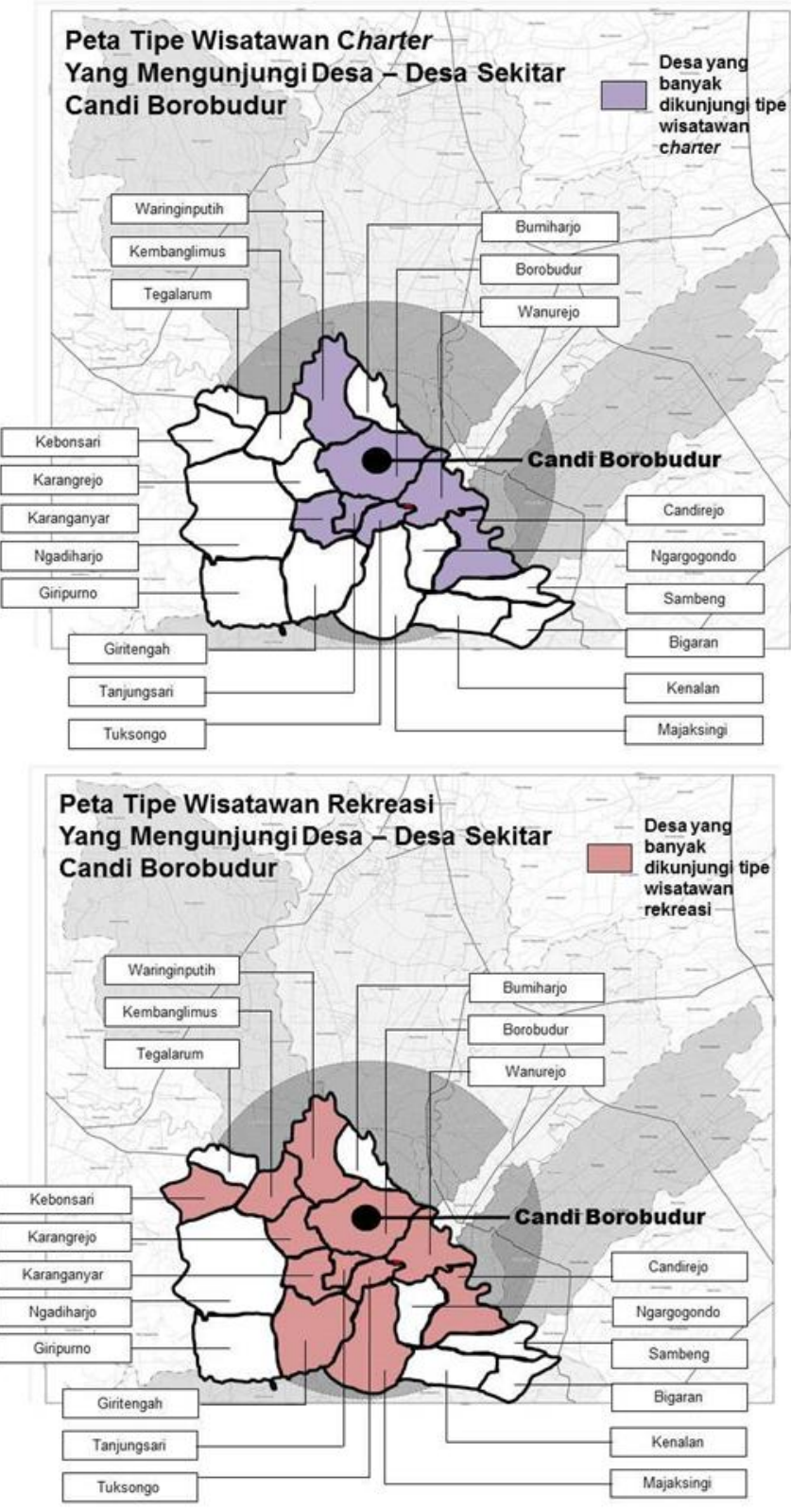

\section{Gambar Peta Tipe Wisatawan Rekreasi Yang Mengunjungi Desa - Desa di Sekitar Candi Borobudur (Sumber : Analisa Penulis)}

Faktor yang berpengaruh terhadap aspek attitudes of decision makers and population of receiving region yaitu perilaku antagonism masyarakat dan pejabat setempat yang kurang mendukung pariwisata.
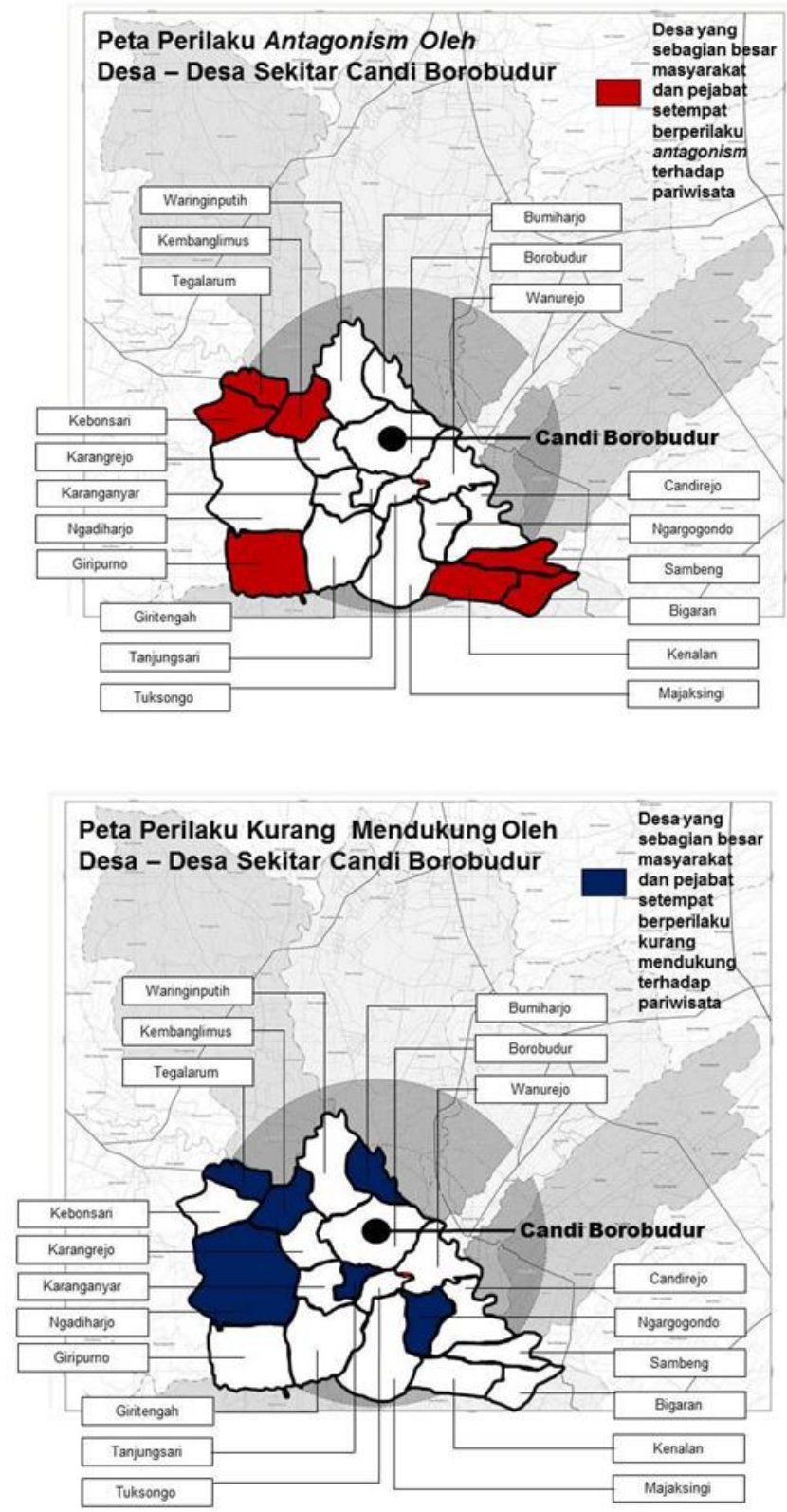

Sumber : Analisa Penulis

\section{Diskusi Temuan}

Dari beberapa faktor yang berpengaruh ada satu temuan desa, yaitu Desa Majaksingi yang letaknya di daerah lereng, tidak dilalui angkutan umum, masyarakat dan pejabat setempat berperilaku antagonism dan kurang mendukung terhadap pariwisata tetapi banyak wisatawan tipe elite yang mengunjungi. Dari hasil analisis penulis, Desa Majaksingi tergolong dalam tipologi desa yang sangat berpengaruh dalam pariwisata Candi Borobudur. Desa Majaksingi memiliki fasilitas rekreasi (akomodasi) hotel bintang lima dan villa mewah, yaitu Hotel Amanjiwo dan Villa Borobudur. Selain memiliki akomodasi yang baik, Desa Majaksingi juga memiliki atraksi sendiri yaitu "Rumah Kamera" yang sudah 
cukup terkenal dan bisa menarik kunjungan wisatawan dari Candi Borobudur. Adanya faktor-faktor yang berpengaruh bisa di interfensi dengan sesuatu yang berbeda karena mempunyai satu keunikan dan itu berdasarkan segmen wisatawan yang mengunjungi Desa Majaksingi.

\section{Strategi Pengembangan}

Untuk mengetahui strategi pengembangan desa desa sekitar Candi Borobudur berdasarkan tipologi, menggunakan analisis IPA (Importance Performance Analysis).

\section{Kesimpulan dan Rekomendasi}

\section{Kesimpulan}

Tipologi desa-desa sekitar Candi Borobudur dipetakan berdasarkan potensi kepariwisataan dengan cara menganalisis temuan-temuan di lapangan kemudian dikompilasikan dengan teori maupun data lainnya. Faktor-faktor yang penulis temukan antara lain:

- Resort, dipengaruhi oleh faktor fasilitas rekreasi dan faktor letak geografis di dataran

- Transport, dipengaruhi olek faktor multi moda dan faktor dilewati rute angkutan umum

- Tourist Behavior, faktor yang paling berpengaruh adalah tipe wisatawan Charterdan faktor tipe wisatawan rekreasi

- Attitudes of decision makers and population of receiving region. faktor yang paling berpengaruh adalah perilaku antagonismdan faktor masyarakat dan pejabat setempat kurang mendukung terhadap pariwisata.

Penentuan strategi pengembangan desa-desa sekitar Candi Borobudur menggunakan metode IPA (Importance Performance Analysis) dan membagi dalam 4 kuadran yaitu ;

- Kuadran I , tidak ada desa yang berada pada kuadran ini.

- Kuadran II, desa sudah berpartisi baik dalam pariwisata dan diharapkan dapat meningkatkan kualitas potensi wisata dan mempertahankan prestasi atau keunggulan yang sudah dimiliki.

- Kuadran III, desa tidak berpartisi baik dalam pariwisata dan tidak terlalu diharapkan dalam pengembangan pariwisata, sehingga pihak pemerintah atau pihak lain yang terkait tidak perlu memprioritaskan atau memberikan perhatian terhadap desa-desa ini.

- Kuadran IV, desa kurang berpartisi baik dalam pariwisata namun masih bisa diharapkan dalam pengembangan pariwisata, sehingga pihak pemerintah atau pihak lain yang terkait diharapkan tidak memprioritaskan alokasi sumber daya terhadap pengembangan desa-desa ini, tetapi diharapkan mengalokasikan sumber daya tersebut kepada faktor-faktor lain yang mempunyai prioritas penanganan lebih tinggi yang masih membutuhkan peningkatan.

\section{Rekomendasi}

Bagi peneliti lain, dari penelitian ini, dapat dilakukan penelitian lanjutan, yaitu:
- Keruangan yang berhubungan dengan sirkulasi pariwisata yang bisa menghubungkan Candi Borobudur dengan desa-desa sekitar Candi Borobudur dengan memanfaatkan potensi-potensi dari masing-masing desa.

- Kualitas akomodasi yang disediakan masyarakat dan pejabat setempat untuk berpartisipasi dalam pariwisata.

\section{Daftar Pustaka}

1) Douglas Pearce (1989), Applied Geography Tourist Developmnet.

2) Doxey, G.V. (1975) Community Development Through Tourism.

3) Martilla, dan James, J.C., (1977), ImportancePerformance Analysis. Journal of Marketing 41, 13 17 